УДК 378.141 .147

DOI:

Вікторія Ворожбіт-Горбатюк, доктор педагогічних наук, професор, професор кафедри освітології та інноваційної педагогіки Харківського національного педагогічного університету імені Г.С. Сковороди

\title{
КОГНІТИВНИЙ КОМПОНЕНТ ІННОВАЦІЙНОЇ ПЕДАГОГІЧНОЇ ДІЯЛЬНОСТІ ВЧИТЕЛЯ
}

У статті розкрито питання сутності і значення когнітивного компонента інноваційної педагогічної діяльності вчителя, сформульовано відповідні практичні поради. Автор стоїть на позиції, щзо сучасна українська школа потребує учителя-інноватора. Такий учитель здатний до осмислення суті та специфіки інновачійних педагогічних технологій, володіє комплексом умінь і навичок застосування таких технологій у професійній діяльності. Учитель-інноватор демонструє компетентності когнітивного спілкування, продукує кластеризацію знання. Для нього характерні асертивність професійної поведінки, критичне мислення.

Особливу цінність мають презентовані у статті універсальні прийоми формування критичного мислення як в учителя, так і в здобувачів. Розроблення відповідних методик, обгрунтування й укладання практичних комплексів визначено перспективою подальшого розроблення заявленої проблеми.

Ключові слова: вища педагогічна освіта; здобувач; зміст педагогічної підготовки; когнітивне спілкування; критичне мислення; педагогічна діяльність; професійна поведінка; суспільство знань; учительігнноватор; університет; икола.

Jim. 8 .

Viktoriia Vorozhbit-Horbatiuk, Doctor of Sciences (Pedagogy), Professor, Professor of the Pedagogy Department, Kharkiv Hhyhoriy Skovoroda National Pedagogical University

\section{COGNITIVE COMPONENT OF TEACHER'S INNOVATIVE PEDAGOGICALACTIVITY}

In the article the author presents the theoretical aspect and practical recommendations for the implementation of the cognitive component of innovative pedagogical activities of teachers.

The article specifies that the understanding of the essence and specifics of innovative pedagogical technologies can be assessed through the characteristics of the teacher: expressiveness (verbal, nonverbal means for accurate understanding), efficiency (focus on rapid successful solving of practical problems), algorithmic (in such activities there is a sequence, it can be reproduced), digestibility (assimilated as a result of learning), adaptability (reproducibility under any circumstances).

The author emphasizes that cognitive communication is always future-oriented. Therefore, such communication involves finding conditions for joint understanding with the applicants and overcoming difficulties. The article highlights and characterizes the levels of formation of cognitive communication. The age characteristics of applicants, advice and methodological resources for the formation of cognitive communication are provided. In primary school it is recommended to widely use the method of explanation: comparison, analogy, identification of differences, indication of the reasons, the creation of simple models. In adolescence, the emphasis on proof is a reduction to the obvious: refutation of the partner's point of view, belief in the correctness of his point of view, the search for convincing arguments, the logic of proof. In adolescence, the emphasis is on refutation: it involves interaction at the level of "strong - strong", finding a mistake, assessing the position of the opponent, making a hypothesis, aligning and assessing reality.

The article presents general requirements for the use of knowledge clustering techniques to develop the experience of cognitive communication. Essential aspects and methods of forming assertive behavior of a teacherinnovator are also described. The methods proposed by the author for the formation of critical thinking in teachers are of interest. The author described those once that can be used in school practice. The universality and variety of methods of forming critical thinking is determined by the prospect of further development of the stated problem.

Keywords: higher pedagogical education; an applicant; the content of pedagogical training; cognitive communication; critical thinking; pedagogical activity; professional behavior; knowledge society; a teacherinnovator; university; a school.

П остановка проблеми. Сьогодення в теорії і практиці підготовки педагогів насичене новаційними процесами. Сучасний учитель змінює ролі в освітньому процесі. Тому системи педагогічної освіти потребують конструктивних практик. На виконання Концепції розвитку педагогічної освіти, Указу Президента України "Про цілі сталого розвитку України на період до 2030 року", відповідних постанов Кабінету Міністрів України, 


\section{КОГНІТИВНИЙ КОМПОНЕНТ ІННОВАЦІЙНОӤ ПЕДАГОГІЧНОЇ ДІЯЛЬНОСТІ ВЧИТЕЛЯ}

Професійного стандарту на групу професій “Вчитель закладу загальної середньої освіти”, Стратегії розвитку вищої освіти в Україні на 20212031 pp. у Харківському національному педагогічному університеті імені Г.С. Сковороди за ініціативи Гаранта професора Л. Зеленської було розроблено освітньо-професійну програму для другого (магістерського) рівня вищої освіти “Освітологія”, галузь знань 01 - науки про освіту, спеціальність 011 - освітні, педагогічні науки [6]. У меті зазначеної ОПП заявлено реалізувати потребу у фахівцеві, який здатний “створювати освітні моделі, контент групового i персоналізованого навчання, системи зворотнього зв' язку “педагог - здобувач - споживач освітньої послуги”, здійснювати моніторинг, експертизу, супервізію в освіті” [там само].

Аналіз основних досліджень і публікацій. Ключовим критерієм якості вищої педагогічної освіти є змістова частина й організація навчання і викладання за конкретною освітньою програмою. Це - питання широкого кола публікацій останніх років. Методологічний базис когнітивного компонента педагогічної діяльності, на наш погляд, актуально презентовано у публікації Т. Полухтович, Ю. Мельничук (2021) [7]. У контексті заявленої теми статті нам видалися грунтовними узагальнення про практики використання елементів когнітивного компонента діяльності - критичного мислення - під час організації індивідуалізації іперсоналізації навчання в умовах роботи на освітній онлайнплатформі у публікації колективу авторів (К. Осадча, В. Осадчій, В. Спірін, В. Круглик, 2021) [5]. Публікації 3 психології містить значущі висновки для формування когнітивного компонента в системі педагогічної освіти і організації відповідних практик: М. Кожевніков [2], Дж. Андерсон [3].

Однак незважаючи на незаперечну актуальність формування когнітивного компонента педагогічної діяльності сучасного учителя, публікацій, де б було презентовано педагогічний дискурс, нема.

Формування мети статті. Метою статті $\epsilon$ конкретизація змістових і процесуальних аспектів формування когнітивного компонента інноваційної педагогічної діяльності вчителя на прикладі змісту освітньо-професійної програми для другого (магістерського) рівня вищої освіти “Освітологія”, галузь знань 01 - науки про освіту, спеціальність 011 - освітні, педагогічні науки, Харківський національний педагогічний університет імені Г.С. Сковороди, Гарант - професор Л. Зеленська.

Виклад основного матеріалу. Когнітивний компонент інноваційної педагогічної діяльності сучасного учителя об'єднує сукупність його знань про суть і специфіку інноваційних педагогічних технологій, комплекс відповідних компетентностей, застосування їх у структурі власної професійної діяльності.

Як відомо, когнітивістика є міждисциплінарною наукою про функціонування будь-якої складної системи обробки даних, здатної набувати, зберігати, використовувати та передавати знання [2]. Відповідно когнітивний компонент інноваційної педагогічної діяльності передбачає звернення уваги до вивчення та моделювання явищ інноватики, пов'язаних зі мисленням, розвитком мислительних процесів, мовлення і поведінки людини.

Варто зазначити, що традиційно виділяють складники когнітивного компонента інноваційної педагогічної діяльності [2; 3]. У пошуку раціонального зерна пропонуємо наше бачення, яке виходить власне із сутності явища конгнітивної педагогічної діяльності вчителя: гностичні вміння вільно оперувати актуальними науковими даними, моніторити інформаційний простір для глибокого і багатостороннього вивчення унікальності особистості здобувача i особистісної виразності, харизми, компетентності відповідних комунікацій. В аналізованій у цій статті ОПП “Освітологія”, гностичні вміння презентовано у змісті компетентностей: ІК, ЗК1, ЗК2, ЗК6, ЗК10, СК2, СК7; здатності проєктування навчального контенту, планувати i реалізовувати заплановане у ситуації невизначеності і постійної динаміки змін у професійній галузі із застосуванням стратегій роботи із різними категоріями здобувачів (віковими, соціального розмаїття, індивідуальними, культурними тощо), у тому числі - проєктувати комунікативний простір професійного й особистісного саморозвитку, а також - такого розвитку здобувачів залежно від віку та інших особливостей. Ці здатності представлено у компетентностях: 3К4, 3К5, ЗК8, ЗК9, СК1, СК5; організаторські (уміння чітко визначати освітні, навчальні цілі, організовувати відповідно до визначених цілей і очікуваних результатів навчальну і самостійну пізнавальну діяльність, яка має виразний розвивальний аспект). Відповідно компетентності: ЗК3, ЗК7, СК3, СК4, СК6; констуктивні уміння і навички відбирати та доцільно дозувати дидактичний і розвивальний матеріал, здійснювати оптимально керівництво процесом учіння, розвитку, володіти раціональним таймінгом. Відповідно компетентності в ОПП “Освітологія": СК8, СК9, СК10, СК11 [6].

Усі складники когнітивного компоненту інноваційної педагогічної діяльності, заявлені в 
ОПП “Освітологія”, передбачають комунікативну компетентність вчителя. Зазначимо тут, що саме когнітивне спілкування має виразні особливості. Про це йтиме мова далі.

Визначивши базисом когнітивного компонента інноваційної педагогічної діяльності здатність учителя бачити і презентувати суть та специфіку педагогічних технологій, гностичні вміння вільно оперувати актуальними науковими даними для вивчення унікальності особистості себе самого і здобувача, ми виділили важливі моменти в ресурсному забезпеченні ОПП “Освітологія”. В організації відповідних комунікацій в середовищі колег, науковців, здобувачів, усіх зацікавлених в якості освіти осіб, важливо уміти визначати цінність технологій, застосунків саме для розвитку особистості. Серед таких бачимо характерні ознаки: виразність. Ця характеристика має чітко давати відповідь на такі питання: чи відповідає тема, ідея концепції, сюжет застосунку актуальним напрямам освіти, соціальному запиту і потребам освітнього закладу? Наскільки ідея інноваційна? Чи зрозуміла ідея для представників широкої громади, наскільки просте і доступне розуміння способів реалізації задуму? Прикладом виразності в ОПП “Освітологія" є перелік освітніх компонент і структурно-логічна схема [6].

Наступною ознакою розуміння суті педагогічних технологій є ефективність. Результатом інновації має стати якість освіти підвищення рівня знань і вмінь, розумового, морального і фізичного розвитку здобувачів відповідно до поставлених цілей; рівень забезпечення якості надання освітніх послуг учасникам освітнього процесу конкретним закладом. Про якість освіти свідчить насамперед iї відповідність освітньому стандарту. У заявленій ОПП програмні результати достатньою мірою відображають Професійний стандарт [8]. Зазначимо тут, що з точки зору інноваційної педагогіки якістю освіти є міра розвиненості особистості, її готовність і спроможність жити самостійним насиченим культурно багатим життям. Учитель-інноватор “ це особистість, здатна брати на себе відповідальність, вчасно враховувати ситуацію соціальних змін. Новації, які поширює учитель в освітній практиці, мають бути алгоритмічними і відтворюваними. Здатність бачити суть і специфіку педагогічних технологій передбачає уміння учителя створювати нові соціо-культурні зв'язки, застосовувати соціальну і професійну колаборацію як ресурси інноваційної діяльності.

Для формування відповідної групи компетентності в системі підготовки учителяінноватора варто особливу увагу приділити когнітивному спілкуванню його призначення ми вбачаємо у пошуку і реалізації умов спільного осмислення та подолання труднощів, психологічних чи соціальних перепон, ймовірних конфліктів, пов'язаних із ситуацією невизначеності, кризи, що гальмують розв'язання завдань розвитку учасників освітнього процесу. Тому учитель-інноватор в програмі професійної підготовки набуває досвіду громадського узгодження, досягнення суспільної злагоди, колаборації соціальних інституцій, які опікуються питаннями освіти і розвитку молоді. В ОПП “Освітологія” когнітивне спілкування формується у здобувачів освітніми компонентами: продуктивна педагогіка, супервізія і коучинг в освіті, актуальні зарубіжні і вітчизняні освітні концепції, низкою дисциплін вільного вибору [6].

Важливо акцентувати, когнітивне спілкування завжди орієнтоване на майбутнє. Таке спілкування не обов'язково відбувається в безпосередній формі діалогу, дискусії або полеміки (наприклад, меседж, книга). Тому розвивальний характер когнітивного спілкування розгортається на трьох основних рівнях [2]: 1) управління комунікацією інформаційно-знаковий рівень; точність передачі інформації від відправника до одержувача, інтерпретація повідомлення одержувачем, порівняння із істинним значенням інформації, відповідно - вплив на зміну поведінки, 2) управління відносинами - рівень емоційно-мотиваційної регуляції спілкування, емоції як фізіологічні активатори, спонукидо активностівучінні, 3) регуляторноінтенційний рівень, або рівень вербальної і смислової регуляції намірів партнерів, узгодження спрямованості в системі сукупних знань, розуміння суті й змісту кінцевого результату, що передбачає вибір мислетворчих засобів і шляхів реалізації цілепокладальної поведінки й способів досягнення поставленої мети.

Виникнення загального інтелектуального ресурсу стає можливим на рівні процесів обміну інформацією, станами (активного тонусу й зараження, групового мотиваційного настрою і настроїв), що забезпечує реадлізацію в ОПП "Освітологія" студентозорієнтованого і трансдисциплінарної моделі навчання [6]. Низка навчальних і дослідницьких практик є підгрунтям ціннісно-орієнтаційної єдності, досвіду й інтегрованості групової інтелектуальної діяльності, вольової погодженості і когерентності викладачів групи забезпечення і здобувачів, які опановують цю ОПП.

Процесуально когнітивний простір вибудовується 


\section{КОГНІТИВНИЙ КОМПОНЕНТІННОВАЦЙНОӤ ПЕДАГОГІЧНОЇ ДІЯЛЬНОСТІ ВЧИТЕЛЯ}

у такий спосіб. Перша стадія пов'язана із необхідністю одержати певну інформацію. Інформація, презентована через мікроблоки, відносно завершені частини навчальнометодичного комплексу слугує базисом для вихідного плану рішення, коли способи переробки інформації представляються здобувачем у магістерській роботі. Ця стадія передбачає особливе спільне забезпечення діалогу партнерів, спрямованого саме на спільний пошук, який має бути вигідний і корисний кожному учасникові. Таким чином когнітивне спілкування стає потужним ресурсом якісного магістерського дослідження у спільному дослідницькому просторі.

Тому тематика магістерських робіт відповідає інтересам і мотивам учасників, їхнім намірам, баченню і перспективам цілепокладань $з$ огляду на майбутню професійну діяльність.

Другим аспектом когнітивного спілкування $\epsilon$ феномен хронотопу (за М. Бахтіним) [4]. Хронотоп дискусії опонентів, де специфічні особливості простору і часу в самій ситуації задають у своїй феноменологічній комбінації неповторність умов спілкування й когнітивних ресурсів для розв'язання завдань діалогів спілкування. Хронотипи впливають на процедуру вироблення рішень. Існування динаміки потреб слід враховувати в практиці комунікативного впливу. Зазначимо, що це положення може бути застосоване і для розв'язання прикладних практичних завдань реалізації цілей ОПП.

Третім аспектом в організації когнітивного спілкування є визначення механізмів прийняття рішень. Так, здобувачів, які опановують ОПП “Освітологія”, орієнтують на подолання бар'єрів спілкування, що передбачає вивчення раціональних, творчих мотиваторів й потреб зростання і досягнень за А. Маслоу [1]. Спектр методичних засобів когнітивного спілкування включає породження засобів розуміння i взаєморозуміння: пояснення, доведення, у спростування. Важливим аспектом когнітивного спілкування $є$ асертивність - це практичний метод у галузі міжособистісної комунікації, який дає змогу: висловлювати свою думку, не боячись заперечувати; $€$ тактикою задоволення справедливих вимог і відмови від неправомірних домагань; допомагає знаходити шляхи примирення з критикою і з власними помилками; дає уміння просити іншого про послугу, не відчуваючи незручності. Для асертивної поведінки характерним $є$ спокій. Мовлення такої людини виразне і зрозуміле, погляд - відкритий. Людина, що поводить себе асертивно, створює навколо себе приємну атмосферу. Вона почувається впевнено ще й тому, що добре орієнтується у сформованій ситуації; нічого не навіюе собі заздалегідь, уміє зустрічати гідно невдачу.

У змісті освітньої компоненти супервізія і коучинг в освіті здобувачі опановують здатності: сказати “ні”; відкрито говорити про почуття i вимоги; встановлювати контакти, починати i закінчувати бесіду; відкрито виражати позитивні та негативні почуття. Джерелом асертивності педагога має бути: почуття професіоналізму, компетентності, тобто, коли він знає, як, якими засобами, методами, техніками здійснити позитивні зміни у спілкуванні зі здобувачами, колегами, попередити конфлікт, зняти напруження. Техніка асертивної поведінки передбачає: впевнену позу, жестикулювання, міміку; відкритий, спокійний погляд; впевнений голос, оптимальну силу голосу і темпу мовлення; асортимент поведінки у “важких” ситуаціях, продуманих заздалегідь; “репетиція" перед дзеркалом варіантів поведінки; формування позитивного “самообразу”. Отже, асертивна поведінка у комунікативному педагогічному процесі - це оптимальний варіант спілкування педагога, який призводить до формування самостійної, відповідальної особистості, здатної успішно долати проблеми - виховні, освітні, психологопедагогічні.

Критичне мислення є результатом когнітивної діяльності. Воно передбачає вміння активно, творчо, індивідуально сприймати інформацію, оптимально застосовувати потрібний вид розумової діяльності, різносторонньо аналізувати інформацію, мати особисту незалежну думку та вміти коректно іiі відстоювати, застосувати здобуті знання на практиці. Навчити мислити критично означає правильно поставити запитання, спрямувати увагу в правильне русло, вчити роботи висновки та знаходити рішення через використання таких форм та методів навчання, як критичний аналіз ситуацій, діалог, рольові та ділові ігри, тренінги, мозковий штурм. До педагогічних умов формування критичного мислення відносять: включення в освітні стандарти і програми цілей формування мислення і змісту, що сприяє умовам розвитку критичності розуму; виділення професійних компетенцій i системи умінь та навичок логічно і критично мислити. Середовище, створене педагогом, має надавати необхідні умови для критичного мислення, але мислити мають самі здобувачі. Група забезпечення ОПП “Освітологія" використовують значний арсенал способів для розвитку критичного мислення: система відкритих запитань “Чому...?”, “Як...?”, “А як 
би...?”, “А якщо...?”, ігри, коли здобувач має прийняти рішення, кероване читання 3 передбаченням, можливість здобувачів працювати у групах, метод прес, читання з позначками, можливість використання різних ідей, життєвих ситуацій для навчання критичного мислення, мозковий штурм, асоціативний кущ, організації вільного часу, працювати над однією проблемою в день, прийоми “"загугли тричі”, “перевір фото”, “не йди за більшістю”, “керуй емоціями”, ведення інтелектуального щоденника, вправи на зменшення рівня егоцентризму, аналіз впливу групи на твоє життя, сповільнення темпу, питання дня (уроку), “займи позицію”, спитайте “Чому?” п’ять разів, метод “автостоп”, “думки на виворіт”, “запитання на запитання”, “думаємо про свої думки”.

Висновки 3 даного дослідження i перспективи подальших розвідок у даному напрямку. Підсумовуючи викладене, зазначимо, що важко переоцінити значення когнітивного компонента інноваційної педагогічної діяльності вчителя. Учитель, який демонструє такий компонент в професійній діяльності, здатний до осмислення суті та продукування інноваційних педагогічних технологій в новій ситуації, володіє компетентностями когнітивного спілкування, використовує ресурси кластеризації знань, проявляє асертивність професійної поведінки, критичне мислення. Перспективами подальшого розроблення заявленої проблеми бачимо розроблення алгоритмів i методичних інструментів для розвитку критичного мислення і асертивної професійної поведінки, узагальнення та презентування відповідного компаративного досвіду.

\section{ЛІТЕРАТУРА}

1. Abraham H. Maslow. Motivation and Personality (2nd ed.). K.: PSYLIB, 2004. P. 31-38.

2. Kozhevnikov Maria. Cognitive style in the context of modern psychology: toward an integrated framework of Cognitive style. Psychological Bulletin. 2007. Vol. 133. №3. P. $464-481$.

3. Андерсон Дж. Когнитивная психология. Пер.с англ. С.Комаров. Санкт-Петербург, Питер, 2002. 96 с.

4. Бахтин М. Формы времени и хронотопа в романе. Вопросы литературы и эстетики. Москва: Худож. лит., 1975. C.234-407.

5. Осадча К., Осадчий В., Спірін О., Круглик В. Реалізація індивідуалізації та персоналізації навчання засобами MOODLE. Молодь і ринок. Дрогобич, 2021. №1/187. DOI: https://doi.org/10.24919/2308$\underline{4634.2021 .228274}$
6. Освітологія ОПП другого (магістерського) рівня вищої освіти ХНПУ імені Г.С.Сковороди : URL:http:// $\mathrm{s} \mathrm{m} \mathrm{c} \cdot \mathrm{h} \mathrm{n} \mathrm{p} \mathrm{u}$. e d u. u a / f i l e $\mathrm{s} /$ Os v \% D $1 \% 96$ tn \% D $1 \% 96$ programi Osvitni programu magistr/2021 rik/Osvitologiya.pdf

7. Полухтович Т., Мельничук Ю. Цінність знань у розвитку особистості. Молодь і ринок. Дрогобич, 2021. №1/187. DOI: https://doi.org/10.24919/2308$\underline{4634.2021 .228342}$

8. Професійний стандарт вчителя закладу загальної середньої освіти 20.12.2020. URL : https://mon.gov.ua/ ua/news/zatverdzheno-profstandart-vchitelyapochatkovih-klasiv-vchitelya-zakladu-zagalnoyiserednoyi-osviti-i-vchitelya-z-pochatkovoyi-osviti

\section{REFERENCES}

1. Abraham, H. Maslow. (2004). Motivation and Personality (2nd ed.). K.: PSYLIB. pp. 31-38. [in English].

2. Kozhevnikov Maria. (2007). Cognitive style in the context of modern psychology: toward an integrated framework of Cognitive style. Psychological Bulletin. Vol. 133. No.3.pp. 464 481. [in English].

3. Anderson Dzh. (2002). Kohnytyvnaia psykholohyia [Cognitive psychology]. English translation S.Komarov. St.Petersburg, 96 p. [in English].

4. Bakhtin, M. (1975). Formy vremeni i khronotopa v romane. Voprosy literatury i estetiki [Forms of time and chronotope in the novel. Questions of literature and aesthetics]. Moscov, pp.234 - 407. [in Russian].

5. Osadcha, K., Osadchyi, V., Spirin, O. \& Kruhlyk, V. (2021). Realizatsiia indyvidualizatsii ta personalizatsii navchannia zasobamy MOODLE [Implementation of individualization and personalization of learning by means of MOODLE]. Youth \& market. Drohobych. No.1/187. DOI: https://doi.org/10.24919/2308-4634.2021.228274 [in Ukrainian].

6. Osvitolohiia OPP druhoho (mahisterskoho) rivnia vyshchoi osvity KhNPU imeni H.S.Skovorody (2021) [Osvitology of the second (master's) level of higher education of KhNPU named after G. S. Skovoroda]. Available at: http://smc.hnpu.edu.ua/files/ O s v \% D $1 \% 96$ t n \% D $1 \% 96$ progra mi Osvitni_programu_magistr/2021_rik/Osvitologiya.pdf[in Ukrainian].

7. Polukhtovych, T. \& Melnychuk, Yu. (2021). Tsinnist znan $u$ rozvytku osobystosti [The value of knowledge in the development of personality]. Youth \& market. Drohobych. No.1/187. DOI: https://doi.org/10.24919/23084634.2021.228342 [in Ukrainian].

8. Profesiinyi standart vchytelia zakladu zahalnoi serednoi osvity 20.12.2020. [Professional standard of a teacher of a general secondary education institution] Available at: https://mon.gov.ua/ua/news/zatverdzhenoprofstandart-vchitelya-pochatkovih-klasiv-vchitelyazakladu-zagalnoyi-serednoyi-osviti-i-vchitelya-zpochatkovoyi-osviti [in Ukrainian].

Стаття надійшла до редакції 27.08.2021

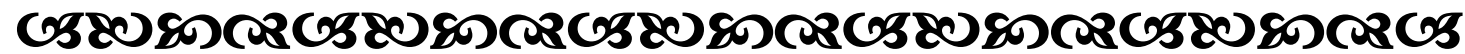

